\title{
Evaluation of the Protective Effect of Citrullus lanatus (Water Melon) Fruit-Parts Extracts on the Liver of Acetaminophen-Intoxicated Albino Rats
}

\author{
M. O. Enemali1, M. E. Asogwa' ${ }^{2}$ C. C. Nweze², G. S. Haruna ${ }^{2 *}$, A. U. Ijeomah ${ }^{2}$ \\ ${ }^{1}$ Department of Applied Biochemistry, Faculty of Biosciences, Nnamdi Azikiwe University, Awka, Nigeria \\ ${ }^{2}$ Department of Biochemistry and Molecular Biology, Faculty of Natural and Applied Sciences, Nasarawa State University, Keffi, \\ Nigeria \\ Email: *sundayharuna@nsuk.edu.ng
}

How to cite this paper: Enemali, M.O., Asogwa, M.E., Nweze, C.C., Haruna, G.S. and Ijeomah, A.U. (2020) Evaluation of the Protective Effect of Citrullus lanatus (Water Melon) Fruit-Parts Extracts on the Liver of Acetaminophen-Intoxicated Albino Rats. Open Access Library Journal, 7: 66807. https://doi.org/10.4236/oalib.1106807

Received: September 9, 2020

Accepted: October 26, 2020

Published: October 29, 2020

Copyright $\odot 2020$ by author(s) and Open Access Library Inc.

This work is licensed under the Creative Commons Attribution International License (CC BY 4.0).

http://creativecommons.org/licenses/by/4.0/

\begin{abstract}
There is always the need to study the bioactive components present in the various parts of edible fruits. This will go a long way to providing an idea of its potential biological benefits when consumed. The current study evaluated the protective effect of $C$. lanatus fruit's endocarp/exocarp, mesocarp and seed extracts on the liver of albino rats. The qualitative and quantitative phytochemical analysis was also done following standard methods. The albino rats were divided into nine groups of five per group and treated thus; group 1 (normal control), group 2, Acetaminophen (2 g/ $/ \mathrm{kg})$, group 3, $200 \mathrm{mg} / \mathrm{kg}$ silymarin $+2 \mathrm{~g} / \mathrm{kg}$ Acetaminophen, group 4, $200 \mathrm{mg} / \mathrm{kg}$ mesocarp $+2 \mathrm{~g} / \mathrm{kg}$ Acetaminophen, group 5, $400 \mathrm{mg} / \mathrm{kg}$, group 6, $200 \mathrm{mg} / \mathrm{kg}$ exocarp, group 7, $400 \mathrm{mg} / \mathrm{kg}$ exocarp, group $8,200 \mathrm{mg} / \mathrm{kg}$ seeds, group $9,400 \mathrm{mg} / \mathrm{kg}$ seeds. The pre-treatment with the extracts lasted for 14 days then acetaminophen administered. The rats were sacrificed after 48 hours of intoxication. Results showed the presence of alkaloids, phenolics, Tannins, steroids and terpenoids and glycosides while saponins and flavonoids were not detected in the endocarp. In the mesocarp, glycosides, phenolics, steroids and terpenoids and tannins were present while Saponins and flavonoids were not detected. Seed extract showed the presence of alkaloids, flavonoids, phenolics, tannins, steroids and terpenoids. Glycosides and saponins were not detected. The activities of AST, ALT and ALP were significantly $(\mathrm{p}<0.05)$ increased in group $2(55.80 \pm$ $3.11,20.80 \pm .84$ and $27.00 \pm 1.22$ respectively) when compared to the normal control group (group 1) $(32.00 \pm 2.12,9.00 \pm 1.00$ and $19.80 \pm 4.49$ respectively). The administration of the extracts (group 4, 5, 6, 7, 8 and 9) led to a
\end{abstract}


significant decrease in the serum activities of AST $(51.40 \pm 1.14,48.60 \pm 7.57$, $39.20 \pm 1.79,48.00 \pm 1.73,51.00 \pm 0.00$ and $47.00 \pm 2.74)$ and ALT $(10.20 \pm$ $1.30,11.20 \pm 1.30,17.20 \pm 2.77,20.00 \pm 0.71,17.60 \pm 0.55$ and $18.20 \pm 1.64)$ when compared with the acetaminophen group (group 2). Photomicrograph images showed normal liver morphology in the control groups 1 and 3, 200 $\mathrm{mg} / \mathrm{kg}$ mesocarp and $400 \mathrm{mg} / \mathrm{kg}$ seed extract administered groups, indicating that the two extract doses better protected the liver against damage occasioned by acetaminophen.

\section{Subject Areas}

Biochemistry

\section{Keywords}

Citrullus lanatus, Acetaminophen, Mesocarp, Endocarp, Seeds, Liver

\section{Introduction}

It is common knowledge that fruits are generally good sources of nutrients such as vitamins and minerals hence the advice by health practitioners and nutritionists for people to always consume fruits. While some fruits may be eaten completely (both the epicarp, mesocarp, endocarp and seeds), others may have some parts eaten and other parts discarded for many reasons ranging from non-palatability to taste. The Biochemical principle underlying the non-palatability may be known or not, hence the need to scientifically study the bioactive components present in plant materials. The plant, $C$. lanatus, commonly known as water melon belongs to the family Cucurbitaceae which is a vine-like (scrambler and trailer) flowering plant and it is mainly cultivated for its fruit because the fruit is the consumable part of the plant. The specie comprises of two major subdivisions and varieties which include $C$. lanatus (Thunb.) and C. lanatus citroides [1]. Molecular data including sequences from the original collection of Thunberg and other relevant type materials show that the sweet watermelon (Citrullus vulgaris Schrad.) and the bitter wooly melon $C$. lanatus (Thunb.) Matsum. as well as Nakai are not closely related to each other [2].

The plant is grown in both tropical and subtropical areas all over the world for its large edible fruit which is a special kind of berry with a hard rind and no internal division, botanically called a pepo. The fruit is usually large, oval or round shape with soft, sweet, juicy flesh and is usually deep red or pink, with many black seeds embedded within the fleshy pulp, although seedless varieties also exist, it is usually eaten raw. The un-ripped portion of the fruit is usually greenish or greenish-white in colour. The outer surface of the ripe and unripe fruit is usually smooth and greenish in color, hence the ripe mature fruit is best identified when broken. The interior of the ripe fruit is typically reddish or pink in colour while the interior of the unripe fruit remains white. 
The rind of the fruit is mid- to dark green and usually mottled or striped, and the flesh, containing numerous pips spread throughout the inside, can be red or pink (most commonly), orange, yellow, green or white [3]. It is one of such medicinal plants that have attracted scientific interest due to its bioactivities [4]. $C$. lanatus is a natural source of antioxidants such as beta carotene [5], vitamin C [6], citrulline [7]. Watermelon with red flesh is also an excellent source of lycopene [8]. The tissue protective effects of watermelon juice have been reported [9]. Furthermore, the protective effects of watermelon juice against hepatotoxins such as carbon tetrachloride $\left(\mathrm{CCl}_{4}\right)$ and paracetamol have been demonstrated [10]. The anti-inflammatory, antioxidat, anti-ulcerogenic and anti-diabetic effects of watermelon have also been documented [11].

The liver is the largest internal organ found in vertebrates. It plays various metabolic functions such as detoxification of various metabolites, protein synthesis, and production of Biochemicals necessary for digestion [13]. In the human body system, it is located in the right upper quadrant of the abdomen,

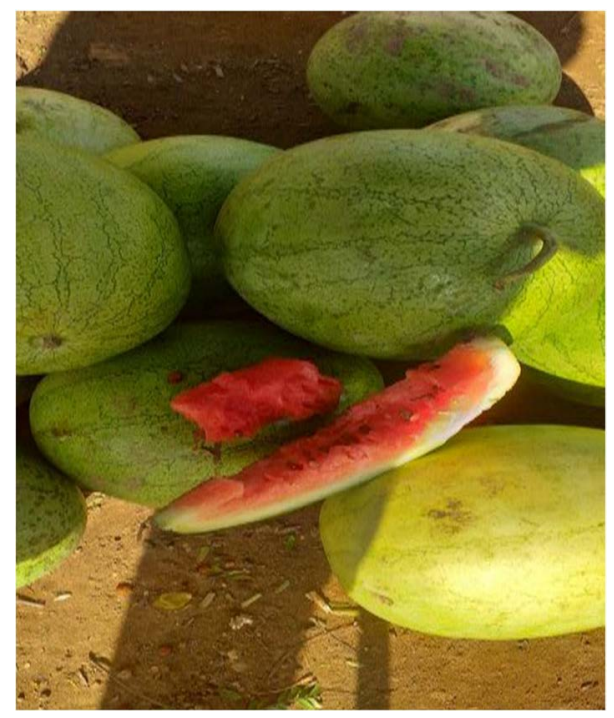

Figure 1. C. lanatus fruits with part of the interior.

Taxonomy of $C$. lanatus.

\begin{tabular}{cc}
\hline Kingdom: & Plantae \\
Division: & Magnoliophyta \\
Class: & Magnoliopsida \\
Order: & Cucurbitales \\
Family: & Cucurbitaceae \\
Scientific name: & Citrullus lanatus \\
Synonyms: & Citrullus vulgaris \\
Genus: & Citrullus \\
Species: & Lanatus \\
\hline
\end{tabular}

[12]. 
below the diaphragm. It also performs other roles in metabolism which include the regulation of glycogen storage, decomposition of red blood cells and the production of hormones. It also helps in the removal of Bilirubin, a toxic substance released when red blood cells are lysed, accumulation of Bilirubin can be very toxic and manifests as jaundice, hence the need to be safely excreted.

The liver is an accessory digestive gland that produces bile, an alkaline compound which helps the breakdown of fats. Bile aids in digestion by the emulsification of lipids. The gallbladder, a small pouch that sits just under the liver, stores bile produced by the liver which is afterwards moved to the small intestine to complete digestion [14]. The liver's highly specialized tissue consisting of mostly hepatocytes regulates a wide variety of high-volume biochemical reactions, including the synthesis and breakdown of small and complex molecules, many of which are necessary for normal vital functions [15]. Hepatic encephalopathy is caused by an accumulation of toxins in the bloodstream that are normally removed by the liver. This condition can result in coma and can prove fatal.

Phytochemicals, also known as plants' secondary metabolites are the biologically active compounds which are present in plants. They are produced by the plants for various uses to the benefit of the plants and are found distributed in various parts of plants namely; leaves, flowers, seeds, barks, roots and pulps, virtually all the living parts of the plants contain phytochemicals. Originally, plants use them for protection against invading elements, hence humans also harness this disease-preventing potential as medicinal agents. Phytochemicals are also known as secondary plant metabolites possess biological properties such as antioxidant activity, antimicrobial effect, modulation of detoxification enzymes, stimulation of the immune system, decrease of platelet aggregation and modulation of hormone metabolism and anticancer property [16]. It is well-known that plants produce these chemicals to protect themselves, but recent researches demonstrate that many phytochemicals can also protect human against diseases [17].

The constituents of watermelon extracts are known for their free radical scavenging activities and antioxidant effect. In the present study, claim in various findings that consuming the fruit may have protective effect on the liver is further investigated. The current study evaluated the protective effect of watermelon extracts pre-treatment on acetaminophen-induced oxidative stress in the liver of albino rats.

\section{Materials and Method}

\subsection{Materials}

\section{Plant Material}

The plant material used in this study include the exocarp, fleshy mesocarp and seeds of the ripe fruit of $C$. lanatus (watermelon). The ripe watermelon fruit was purchased from Keffi market and identified at the Department of Plant Science and Biotechnology of Nasarawa State University, Keffi, Nigeria. 


\section{Experimental animal models}

The study was carried out using 45 male wistar albino rats, weighing between 79 - $220 \mathrm{~g}$ which were purchased from National Veterinary Research Institute (NVRI) Vom, Jos, Nigeria. The animals were housed in well ventilated cages in the animal house of the Department of Biochemistry and Molecular Biology, Faculty of Natural and Applied Sciences, Nasarawa State University, Keffi. They were fed with water and starter mash (vital feed) for two weeks (14 days) to acclimatize them to laboratory condition before commencement of the study.

\section{Acetaminophen/silymarin}

The drug, Acetaminophen was a research support from Emzor Pharmaceutical Ltd, Lagos while silymarin is a branded drug (Sylibon 140) from Micro Laboratory Ltd, India (purchased from a pharmaceautical shop in Keffi). Solutions were made in appropriate volumes of distilled water in tightly sealed sample bottles, and refrigerated in readiness for the study.

\subsection{Methods}

\section{Preparation of the $C$. lanatus sample}

The $C$. lanatus fruit was washed under a running tap and then cut into medium pieces using knife. The fleshy mesocarp, exocarp/endocarp of the water melon were blended separately with a blending machine. The blended samples were separately soaked in distilled water for 24 hours for extraction of the bioactive constituents, after which it was sieved using muslin cloth, after sieving the juice was filtered using filter paper, the filtrate was concentrated using water bath to get the extract. The seeds was air dried for two weeks, after air drying, the seeds was pounded and soaked in ethanol and tightly covered and stored for 48 hours, after which it was sieved and filtered, the filtrates was concentrated using water bath to get the seed extract. The seed, fleshy mesocarp and exocarp/endocarp crude extracts were then stored in a refrigerator until commencement of the experiment.

Qualitative Phytochemical Analysis of the aqueous extracts of $C$. lanatus mesocarp, exocarp/endocarp and ethanol extract of the seed.

The preliminary phytochemical screening of the aqueous extracts of $C$. lanatus mesocarp, exocarp/endocarp and ethanol extract of the seed was carried out in order to ascertain the presence of some plant secondary metabolites and those detected were further quantified. Both determinations were done by utilizing standard conventional protocols as illustrated by [18] [19] [20]. The concentration (C) of the various phytochemical constituents was calculated thus:

$$
\begin{gathered}
\mathrm{C}(\mathrm{mg} / 100 \mathrm{~g})=\frac{\text { Absorbance of sample }}{\text { Absorbance of standard }} * \mathrm{D} \\
\mathrm{D}=\text { dilution factor }=\text { (total volume/weight }) \text { of extract }
\end{gathered}
$$

\section{Test for alkaloids (general test)}

A quantity $(1 \mathrm{~g})$ of extract was mixed with $10 \mathrm{ml} 2 \% \mathrm{HCl}$, heated for $5 \mathrm{mi}$ nutes then filtered. Filtrate $(1 \mathrm{ml})$ was put in two test tubes each, Test tube $\mathrm{I}+1$ 
$\mathrm{ml}$ Mayer's reagent, creamy white precipitate was observed. Test tube II $+1 \mathrm{ml}$ Wagner's reagent, reddish-brown precipitate was observed (indicating the presence of alkaloids).

\section{Test for glycosides (Fehling's test)}

A quantity $(1 \mathrm{~g})$ of extract was mixed with distilled water $(10 \mathrm{ml})$, boiled for 5 minutes before it was filtered. $2 \mathrm{ml}$ of filtrate plus $2 \mathrm{ml}$ dilute ammonia $(2 \mathrm{ml}$ filtrate $+2 \mathrm{ml}$ dil. $\mathrm{NH}_{3}(\mathrm{aq})$ ), the solution was then added to $200 \mu \mathrm{l}$ of Fehling's solutions A and $200 \mu$ l Fehling's solutions B. The solution was heated for $10 \mathrm{mi-}$ nutes in a water bath. A change of colouration to brick red indicates the presence of glycoside.

Test for steroids

To $1 \mathrm{~g}$ of extract was added $2 \mathrm{ml}$ of acetic anhydride. The solution was subsequently added $2 \mathrm{ml}$ of concentrated $\mathrm{H}_{2} \mathrm{SO}_{4}$ carefully. A brownish colouration was observed which indicated the presence of steroids.

\section{Test for flavonoids}

A quantity of the sample $(1 \mathrm{~g})$ was heated with $10 \mathrm{ml}$ ethyl acetate in boiling water for 3 minutes. The mixture was filtered, and the filtrate was used for the following tests.

1) Ammonium test: $4 \mathrm{ml}$ of the filtrate was shaken with $1 \mathrm{ml}$ of dilute ammonium solution to obtain two layers. The layers were allowed to separate. A yellow precipitate in the ammonium layer indicates the presence of flavonoids.

2) Aluminium chloride test: $4 \mathrm{ml}$ of the filtrate was shaken with $1 \mathrm{ml}$ of $1 \%$ aluminium chloride solution, yellow colouration indicates the presence of flavonoids.

\section{Test for tannins (Ferric chloride Method)}

To $1 \mathrm{~g}$ of extract was added to $10 \mathrm{ml}$ of $45 \%$ ethanol, boiled for 5 minutes and then filtered. To $1 \mathrm{ml}$ filtrate, $200 \mu \mathrm{l}$ of ferric chloride was added. An observation of brownish green precipitate indicates the presence of tannins.

\section{Test for saponin}

A quantity $(1 \mathrm{~g})$ of extract was dissolved in $10 \mathrm{ml}$ distilled water, warmed for a minute and then filtered. To $1 \mathrm{ml}$ filtrate was added $4 \mathrm{ml}$ of distilled water, shaken thoroughly for 5 minutes before allowing to stand for 1 minute. Persistence foam formed indicates the presence of saponins.

\section{Test for terpenoids}

A quantity $(1 \mathrm{~g})$ of the extract was dissolved in ethanol and $1 \mathrm{ml}$ of acetic anhydride was added to the solution. A few drops of concentrated $\mathrm{H}_{2} \mathrm{SO}_{4}$ was then added to the solution. A change in colour from pink to violet shows the presence of terpenoids.

\section{Test for phenolics}

To $1 \mathrm{~g}$ of the extract was added $2 \mathrm{ml}$ of distilled water. Then $0.5 \mathrm{ml} \mathrm{Na} \mathrm{CO}_{3}$ and $0.5 \mathrm{ml}$ Folin Ciocalteau reagent was subsequently added. Formation of a blue-green colour indicates the presence of phenols.

Quantitative phytochemical analysis of the aqueous extracts of $C$. lanatus 
mesocarp, exocarp/endocarp and ethanol extract of the seeds.

The quantitative phytochemical analysis was done using the method of [18] [19].

Quantitative Determination of Flavonoids Content

A quantity $(0.2 \mathrm{~g})$ of extract was macerated with $20 \mathrm{ml}$ of ethylacetate for 10 minutes and centrifuged for 5 minutes. $5 \mathrm{ml}$ of the supernatant was transferred into triplicate test tubes and to each of them were added $5 \mathrm{ml}$ of $1 \mathrm{M}$ ammonium. The mixture was shaken vigorously for 2 to 5 minutes, centrifuged for 5 minutes and the upper layer discarded. The absorbance of the lower layer was then taken at wavelength of $470 \mathrm{~nm}$ against the corresponding blank.

Quantitative Determination of Tannins Content

A quantity $(0.2 \mathrm{~g})$ of extract was macerated with $20 \mathrm{ml}$ of methanol for 10 minutes and centrifuged for 5 minutes. $2 \mathrm{ml}$ of the supernatant was then transferred into triplicate test tubes and to the tubes were added $3 \mathrm{ml}$ of methanol, 0.3 $\mathrm{ml}$ of $0.1 \mathrm{M}$ ferric chloride in $0.1 \mathrm{M} \mathrm{HCl}$ and $0.3 \mathrm{ml}$ of $0.8 \mathrm{mM}$ potassium ferricyanide. The solution shaken thoroughly and the absorbance taken against the corresponding blank at $720 \mathrm{~nm}$ after 5 minutes

\section{Quantitative Determination of alkaloids}

A known quantity of the extract $(0.2 \mathrm{~g})$ was macerated with $10 \mathrm{ml}$ of ethanol and $10 \mathrm{ml}$ of $20 \%$ sulphuric acid for 10 minutes. The macerated sample was then centrifuged for 5 minutes and $0.5 \mathrm{ml}$ of the supernatant transferred into triplicate test tubes. To the triplicate test tubes were added $2.5 \mathrm{ml}$ of $60 \%$ sulphuric acid and $2.5 \mathrm{ml}$ of $0.5 \%$ formaldehyde in $60 \%$ sulphuric acid. The solution was then mixed thoroughly and allowed to stand for 3 hours. The absorbance was taken at wavelength of $565 \mathrm{~nm}$ against the corresponding blank.

Quantitative determination of steriods content

A quantity of extract $(0.2 \mathrm{~g})$ was macerated in $7 \mathrm{ml}$ of ethanol. It was filtered and $1 \mathrm{ml}$ of chromagen solution was added to $1 \mathrm{ml}$ of the filtrate and allowed to stand for 30 minutes. The absorbance was thereafter read at $550 \mathrm{~nm}$.

Quantitative determination of terpenoids content

A known quantity of extract $(0.2 \mathrm{~g})$ was macerated in $10 \mathrm{ml}$ of ethanol and then filtered. To $0.5 \mathrm{ml}$ of filtrate was added $0.5 \mathrm{ml}$ of phosphomolybdic acid, 0.5 $\mathrm{ml}$ of concentrated sulphuric acid and $5 \mathrm{ml}$ of ethanol. The absorbance was subsequently read at $700 \mathrm{~nm}$.

\section{Quantitative determination of total phenolics content}

A known quantity of extract ( $1 \mathrm{~g}$ ) was macerated with $20 \mathrm{ml}$ of $80 \%$ ethanol for 10 minutes and centrifuged for 5 minutes. $2 \mathrm{ml}$ of the supernatant was transferred into triplicate test tubes to which was added $3 \mathrm{ml}$ of water, $0.5 \mathrm{ml}$ of folin-ciocalteu, mixed and allowed to stand for 5 minutes. $2 \mathrm{ml}$ of $20 \%$ sodium carbonate was later added; the solution mixed thoroughly by shaking and allowed to stand for another 30 minutes. The absorbance of the resulting solution was then determined at wavelength of $760 \mathrm{~nm}$ against the corresponding blank.

Quantitative determination of glycosides content

The extract $(1 \mathrm{~g})$ was macerated with $50 \mathrm{ml}$ of distilled water and filtered. To 
the filtrate $(1 \mathrm{ml}), 4 \mathrm{ml}$ of alkaline pirate solution was added. The mixture was boiled for 5 minutes and allowed to cool. The absorbance was read at $490 \mathrm{~nm}$.

\section{Experimental Design for the in vivo studies}

The albino rats were weighed and divided into nine (9) groups of five (5) animals per group and treated thus;

Group 1 (normal control): The rats in this group were given only water and starter mash.

Group 2 (negative control): They were given water, feed and Acetaminophen $(2 \mathrm{~g} / \mathrm{kg})$.

Group 3 (standard control); were given water, feed and silymarin (200 $\mathrm{mg} / \mathrm{kg}$ ) pre-treatment for two (2) weeks, then fasted for up to seven hours, followed by intoxication with Acetaminophen $(2 \mathrm{~g} / \mathrm{kg})$.

Group 4; were given water, feed and aqueous extract of water melon mesocarp $(200 \mathrm{mg} / \mathrm{kg})$ pre-treatment for two (2) weeks, then fasted for seven hours, followed by intoxication with Acetaminophen $(2 \mathrm{~g} / \mathrm{kg})$.

Group 5; were given water, feed and aqueous extract of water melon mesocarp $(400 \mathrm{mg} / \mathrm{kg})$ pre-treatment for two (2) weeks, then fasted for seven hours, followed by intoxication with Acetaminophen $(2 \mathrm{~g} / \mathrm{kg})$.

Group 6: The rats were given water, feed and aqueous extract of water melon exocarp (200 mg/kg) pre-treatment for two (2) weeks, then fasted for up to seven hours, followed by intoxication with Acetaminophen $(2 \mathrm{~g} / \mathrm{kg})$.

Group 7: The rats were given water, feed and aqueous extract of water melon exocarp (400 mg/kg) pre-treatment for two (2) weeks, then fasted for up to seven hours, followed by intoxication with Acetaminophen $(2 \mathrm{~g} / \mathrm{kg})$.

Group 8: The rats were given water, feed and ethanol extract of water melon seeds $(200 \mathrm{mg} / \mathrm{kg})$ pre-treatment for two (2) weeks, then fasted for up to seven hours, followed by intoxication with acetaminophen $(2 \mathrm{~g} / \mathrm{kg})$.

Group 9: The animals were given water, feed and ethanol extract of the water melon seeds $(400 \mathrm{mg} / \mathrm{kg}$ ) pre-treatment for two (2) weeks, then fasted for up to seven hours, followed by intoxication with acetaminophen $(2 \mathrm{~g} / \mathrm{kg})$.

The rats were humanely sacrificed after 48 hours of intoxication under anaesthesia (Diethylether) and blood collected for analysis of Biochemical parameters.

The livers were quickly harvested and transferred immediately into ice-cold $0.25 \mathrm{M}$ sucrose buffered ( $\mathrm{pH}$ 7.4) solution and the other part of the liver were preserved in formalin for Histopathological studies.

\section{Preparation of liver homogenate}

The livers were carefully removed, trimmed of extraneous tissue and rinsed in ice-cold $0.25 \mathrm{M}$ sucrose buffer. They were weighed $(2 \mathrm{~g})$ and homogenized in 4 $\mathrm{mls}$ of ice-cold $0.25 \mathrm{~m}$ sucrose buffer ( $\mathrm{pH}$ 7.4). The homogenates were centrifuged first at $6000 \mathrm{rpm}$ for 6 minutes to remove nuclear debris. The supernatant obtained were used for analysis.

\section{Analysis of Liver function markers \\ Determination of Alkaline phosphatase (ALP)}

Alkaline phosphatase activity was assayed by following the method outlined in 
RANDOX kit for ALP assay.

Principle: The principle of this method is based on the reaction of alkaline phosphate and a colourless substrate of phenolphthalein monophosphate, giving rise to phosphoric acid and phenolphthalein which at alkaline $\mathrm{pH}$ values, turn pink that can be determined spectrophotometrically.

$$
\text { P-nitrophenylphhosphate }+\mathrm{H}_{2} \mathrm{O} \stackrel{\text { ALP }}{\longrightarrow} \mathrm{PO}_{4}^{2-}+\text { P-nitrophenol (pink at } \mathrm{pH}=9.8 \text { ) }
$$

Method: The blank and sample test tubes were set up in duplicates and 0.05 $\mathrm{ml}$ of sample was pipette into the sample test tubes. $0.05 \mathrm{ml}$ of distilled water was pipetted into the blank tube. Three milliliters $(3.0 \mathrm{ml})$ of substrate were pipetted into each tube respectively, which was then mixed and the initial absorbance taken at $405 \mathrm{~nm}$. The stop watch was started and the absorbance of the sample and the blank read again three more times at one minute intervals.

Calculation: alkaline phosphatase activity was calculated as follows:

$$
\text { Activity of ALP }(\text { in U/L })=\frac{\text { Absorbance of sample }}{\text { Absorbance of standard }} \times 3300
$$

\section{Determination of Alanine Aminotransferase (ALT) activity}

This was done by following the method outlined in ALT assay kit.

Principle: ALT is measured by monitoring the concentration of pyruvate hydrazone formed with 2, 4-dinitrophenylhydrazine. The colour intensity is measured against the blank at $540 \mathrm{~nm}$.

Briefly, the blank and sample test tubes were set up in duplicates. $0.1 \mathrm{ml}$ of serum was pipetted into the sample tubes. To these were added $0.5 \mathrm{ml}$ buffer solution containing phosphate buffer, L-alanine and oxoglutarate. The mixtures were thoroughly mixed and incubated for exactly 30 minutes at $37^{\circ} \mathrm{C}$ and $\mathrm{pH}$ 7.4. A volume, $0.5 \mathrm{ml}$ of reagent containing 2, 4-dinitrophenylhydrazine was later added to both tubes while $0.1 \mathrm{ml}$ of sample was added to sample blank tube. The tubes were mixed thoroughly and incubated for exactly 20 minutes at $25^{\circ} \mathrm{C}$. Five militres of sodium hydroxide solution was then added to each tube and mixed. The absorbance was read against the blank after 5 minutes at $540 \mathrm{~nm}$ [21].

\section{Determination of Aspartate Aminotransferase (AST) activity}

AST activity was assayed by following the method as outlined in RANDOX kit for AST assay.

Principle: AST is measured by monitoring the concentration of oxaloacetate hydrazone formed with 2, 4-dinitrophenylhydrazine. The colour intensity is measured against the blank at $546 \mathrm{~nm}$.

Briefly, the blank and sample test tubes were set up in duplicates. A volume, $0.1 \mathrm{ml}$ of serum was pipetted into the sample tubes and $0.5 \mathrm{ml}$ of reagent 1 was pipette into both sample and blank tubes.

The solutions were thoroughly mixed and incubated for exactly 30 minutes at $37^{\circ} \mathrm{C} \mathrm{ml}$ and $\mathrm{pH}$ 7.4. $0.5 \mathrm{ml}$ of Reagent 2 containing 2, 4-dinitrophenylhydrazine was added into all the test tubes followed by $0.1 \mathrm{ml}$ of sample into the blank tubes. The tubes were mixed thoroughly and incubated for exactly 20 minutes at $25^{\circ} \mathrm{C}$ 
and $5.0 \mathrm{ml}$ of sodium hydroxide solution was then added to each tube and mixed. The absorbance was read against the blank after 5 minutes at $546 \mathrm{~nm}$ [21].

\section{Histopathological examination of the Liver}

This was carried out as described by [22]. At the end of the administration period, tissue sections of the liver were collected for histopathological examination. The samples were fixed in $10 \%$ phosphate buffered formalin for a minimum of 48 hours before commencement of tissue preparation processess. The tissues were trimmed, dehydrated in 4 grades of alcohol $(70 \%, 80 \%, 90 \%$ and absolute alcohol), cleared in 3 grades of xylene and embedded in molten wax. On solidifying, the blocks were sectioned, $5 \mu \mathrm{m}$ thick with a rotary microtome, floated in water bathe and incubated at $60^{\circ} \mathrm{C}$ for 30 minutes. The $5 \mu \mathrm{m}$ thick sectioned tissues were subsequently cleared in 3 grades of xylene and rehydrated in 3 grades of alcohol $(90 \%, 80 \%$ and $70 \%)$. The sections were then stained with Hematoxylin for 15 minutes. Blueing was done with ammonium chloride. Differentiation was done with $1 \%$ acid alcohol before counterstaining with Eosin. Permanent mounts were made on degreased glass slides using a mountant; DPX. The prepared slides were examined with a Motic ${ }^{\text {Tx }}$ compound light microscope using $\times 4$, $\times 10 \times 16$ and $\times 40$ objective lenses. The photomicrographs were taken using a Motic $^{\text {Tix }} 9.0$ megapixels microscope camera at $\times 160$ magnification.

\section{Statistical analysis}

Data obtained were analyzed using one-way ANOVA with the help of a software, SPSS. Further test for level of significance were carried out using LSD (least significant difference) and Duncan test. The acceptable level of significance was 0.05 for all the data.

\section{Results and Discussion}

\subsection{Results}

Qualitative phytochemical composition of aqueous extract of endocarp/exocarp, mesocarp and ethanol extract of seeds of citrullus lanatus.

The qualitative phytochemical analysis of aqueous extract of endocarp, mesocarp and ethanol extract of seed of citrullus lanatus shows the presence of alkaloids, phenolics, Tannins, steroids and terpenoids and glycosides while saponins and flavonoids were not detected in the endocarp. In the mesocarp, glycosides, phenolics, steroids and terpenoids and tannins were present while Saponins and flavonoids were not detected in the mesocarp. The seeds showed the presence of alkaloids, flavonoids, phenolics, tannins, steroids and terpenoids while glycosides and saponins were not detected in the seeds as shown in Table 1.

Quantitative Phytochemical composition of aqueous extract of exocarp/endocarp, mesocarp and ethanol extract of seeds of $C$. lanatus.

The quantitative phytochemical analysis showed that glycosides were higher in the endocarp/exocarp $(6.40 \pm 0.04 \mathrm{mg} / 100 \mathrm{~g})$ followed by the mesocarp ( 6.20 $\pm .24 \mathrm{mg} / 100 \mathrm{~g}$ ) and absent in the seeds. The concentration of total phenolics was $(7918.56 \pm 181.58 \mathrm{mg} / 100 \mathrm{~g})$ in the mesocarp, $7108.61 \pm 286.50 \mathrm{mg} / 100 \mathrm{~g}$ in 
the endocarp and $1073.33 \pm 29.99 \mathrm{mg} / 100 \mathrm{~g}$ in the seeds respectively with its highest concentration been in the mesocarp extract and least in the seed extract. Tannins concentrations was also highest in the mesocarp $(15.62 \pm 0.01 \mathrm{mg} / 100$ g) followed by $13.64 \pm 0.26 \mathrm{mg} / 100 \mathrm{~g}$ in the endocarp and $8.44 \pm 1.56$ in the seed extracts. Flavonoids concentration was $62.13 \pm 0.87 \mathrm{mg} / 100 \mathrm{~g}$ in the seeds and absent in the endocarp and mesocarp. Alkaloids concentration in the mesocarp was $1007.51 \pm 5.42 \mathrm{mg} / 100 \mathrm{~g}$, which was the highest, followed by $588.71 \pm 24.12$ $\mathrm{mg} / 100 \mathrm{~g}$ in the endocarp and $30.80 \pm 5.73$ in the seed extracts. For steroids, the concentrations were $4.60 \pm 0.05 \mathrm{mg} / 100 \mathrm{~g}$ in the endocarp (the highest), $2.84 \pm$ $0.12 \mathrm{mg} / 100 \mathrm{~g}$ in the mesocarp and $0.19 \pm 0.01 \mathrm{mg} / 100 \mathrm{~g}$ in the seeds. Terpenoids in the mesocarp was $145.49 \pm 10.15 \mathrm{mg} / 100 \mathrm{~g}, 59.95 \pm 4.90 \mathrm{mg} / 100 \mathrm{~g}$ in the seeds and $5.20 \pm 0.50 \mathrm{mg} / 100 \mathrm{~g}$ in the endocarp/exocarp (Table 2).

Effect of aqueous extract of endocarp/exocarp, mesocarp and ethanol extract of seeds of $C$. lanatus pre-treatment on serum liver enzymes of acetaminophen treated wistar rats.

As shown in Table 3, the activities of AST, ALT and ALP were significantly ( $p$

Table 1. Qualitative phytochemical composition of aqueous extract of endocarp/exocarp, mesocarp and ethanol extract of seeds of $C$. lanatus.

\begin{tabular}{cccc}
\hline Phytochemical & Endocarp & Mesocarp & Seeds \\
Glycosides & + & + & - \\
Saponins & - & - & - \\
Alkaloids & + & + & + \\
Flavonoids & - & + & + \\
Phenolics & + & + & + \\
Tannins & + & + & + \\
Steroids & + & + & + \\
Terpenoids & + & + & + \\
\hline
\end{tabular}

Key: $+=$ present, $-=$ absent

Table 2. Quantitative Phytochemical composition of aqueous extract of endocarp, mesocarp and ethanol extract of seeds of $C$. lanatus.

\begin{tabular}{cccc}
\hline Phytochemical & Endocarp $(\mathrm{mg} / 100 \mathrm{~g})$ & Mesocarp $(\mathrm{mg} / 100 \mathrm{~g})$ & Seeds $(\mathrm{mg} / 100 \mathrm{~g})$ \\
\hline Glycosides & $6.40 \pm 0.04^{\mathrm{a}}$ & $6.20 \pm 0.24^{\mathrm{a}}$ & $0.00 \pm 0.00^{\mathrm{b}}$ \\
Total phenolics & $7108.61 \pm 286.50^{\mathrm{c}}$ & $7918.56 \pm 181.58^{\mathrm{d}}$ & $1073.33 \pm 29.99^{\mathrm{e}}$ \\
Tannins & $13.64 \pm 0.26^{\mathrm{f}}$ & $15.62 \pm 0.01^{\mathrm{g}}$ & $8.44 \pm 1.56^{\mathrm{h}}$ \\
Flavonoids & $0.00 \pm 0.00^{\mathrm{i}}$ & $0.00 \pm 0.00^{\mathrm{i}}$ & $62.13 \pm 0.87^{\mathrm{j}}$ \\
Alkaloids & $588.71 \pm 24.12^{\mathrm{k}}$ & $1007.51 \pm 5.42^{\mathrm{l}}$ & $30.80 \pm 5.73^{\mathrm{m}}$ \\
Steroids & $4.60 \pm 0.05^{\mathrm{n}}$ & $2.84 \pm 0.12^{\mathrm{o}}$ & $0.19 \pm 0.01^{\mathrm{p}}$ \\
Terpenoids & $5.20 \pm 0.50^{\mathrm{q}}$ & $145.49 \pm 10.15^{\mathrm{r}}$ & $59.95 \pm 4.90^{\mathrm{s}}$ \\
\hline
\end{tabular}

Results are expressed as Means \pm SD $(n=3)$. Mean values with different letters as superscripts across the periods (i.e. horizontal comparison) are considered significant at $\mathrm{p}<0.05$. 
Table 3. Effect of aqueous extracts of endocarp/exocarp, mesocarp and ethanol extract of seed of $C$. lanatus pre-treatment on serum liver enzymes level in acetaminophen intoxicated rats.

\begin{tabular}{cccc}
\hline Group & AST (U/L) & ALT (U/L) & ALP (U/L) \\
\hline Group 1 (NC) & $32.00 \pm 2.12^{\mathrm{a}}$ & $9.00 \pm 1.00^{\mathrm{f}}$ & $19.80 \pm 4.49^{\mathrm{k}}$ \\
Group 2 (NeC) + Acetaminophen & $55.80 \pm 3.11^{\mathrm{b}}$ & $20.80 \pm .84^{\mathrm{i}}$ & $27.00 \pm 1.22^{\mathrm{m}}$ \\
Group 3 (SC) (acetaminophen + silymarin) & $42.60 \pm 2.88^{\mathrm{c}}$ & $14.20 \pm .84^{\mathrm{j}}$ & $17.00 \pm 6.78^{\mathrm{k}}$ \\
Group 4 (200 mg/kg of Mesocarp) & $51.40 \pm 1.14^{\mathrm{d}}$ & $10.20 \pm 1.30^{\mathrm{f}}$ & $22.20 \pm 1.79^{\mathrm{l}}$ \\
Group 5 (400 mg/kg of Mesocarp) & $48.60 \pm 7.57^{\mathrm{d}}$ & $11.20 \pm 1.30^{\mathrm{gf}}$ & $32.60 \pm 1.52^{\mathrm{m}}$ \\
Group 6 (200 mg/kg of Endocarp) & $39.20 \pm 1.79^{\mathrm{c}}$ & $17.20 \pm 2.77^{\mathrm{h}}$ & $24.60 \pm 1.14^{\mathrm{m}}$ \\
Group 7 (400 mg/kg of Endocarp) & $48.00 \pm 1.73^{\mathrm{e}}$ & $20.00 \pm 0.71^{\mathrm{i}}$ & $28.80 \pm 1.30^{\mathrm{m}}$ \\
Group 8 (200 mg/kg of Seed) & $51.00 \pm 0.00^{\mathrm{e}}$ & $17.60 \pm 0.55^{\mathrm{h}}$ & $28.80 \pm 1.64^{\mathrm{m}}$ \\
Group 9 (400 mg/kg of Seed) & $47.00 \pm 2.74^{\mathrm{e}}$ & $18.20 \pm 1.64^{\mathrm{h}}$ & $30.60 \pm 0.54^{\mathrm{m}}$ \\
\hline
\end{tabular}

Results are expressed in Means $\pm S D(n=5)$. Mean values with different letters as superscripts down the groups are considered significant at $\mathrm{p}<0.05 . \mathrm{NC}=\mathrm{Normal}$ control, $\mathrm{NeC}=$ Negative control, $\mathrm{SC}=$ Standard control .

$<0.05)$ increased in group $2(55.80 \pm 3.11,20.80 \pm .84$ and $27.00 \pm 1.22$ respectively) when compared to the normal control group (group 1) $(32.00 \pm 2.12,9.00$ \pm 1.00 and $19.80 \pm 4.49$ respectively). However, the administration of the extracts (group 4, 5, 6, 7, 8 and 9) led to a significant decrease in the serum activities of AST $(51.40 \pm 1.14,48.60 \pm 7.57,39.20 \pm 1.79,48.00 \pm 1.73,51.00 \pm 0.00$ and $47.00 \pm 2.74)$ and $\operatorname{ALT}(10.20 \pm 1.30,11.20 \pm 1.30,17.20 \pm 2.77,20.00 \pm 0.71$, $17.60 \pm 0.55$ and $18.20 \pm 1.64$ ) when compared with the negative control group (group 2). The administration of the extracts in group 5,7,8 and 9 increased the activities of ALP but the increase was not significant when compared to the negative control group (group 2) while the administration of the extracts in group 4 and 6 decreased when compared to the negative control group (group 2).

The effect of pre-treatment with extracts of citrullus lanatus on the histopathology of livers of wistar rats treated with $2 \mathrm{gkgbw}$ single dose of acetaminophen

Liver section of normal control group

Liver section of normal control (group 1, Plate 1) showed the normal histology of the rodent liver. Each section showed hepatic lobules with central veins (V) surrounded by hepatocytes arranged in radially oriented interconnecting cords, seperated by normal sized hepatic sinusoids. The hepatic cords appear to terminate at the periphery of the hepatic lobules where they meet with the components of the portal area (hepatic artery, hepatic vein and bile ductule). Portal area $(\mathrm{P}) . \mathrm{H} \& \mathrm{E} \times 160$.

Liver section of negative control (group 2)

Liver section of group 2 (Plate 2) showed a randomly multifocal necrosis of the hepatocytes. $\mathrm{H} \& \mathrm{E} \times 160$.

Liver section of standard control (group 3)

Liver section of standard control (group 3) (Plate 3) showed the normal histology 


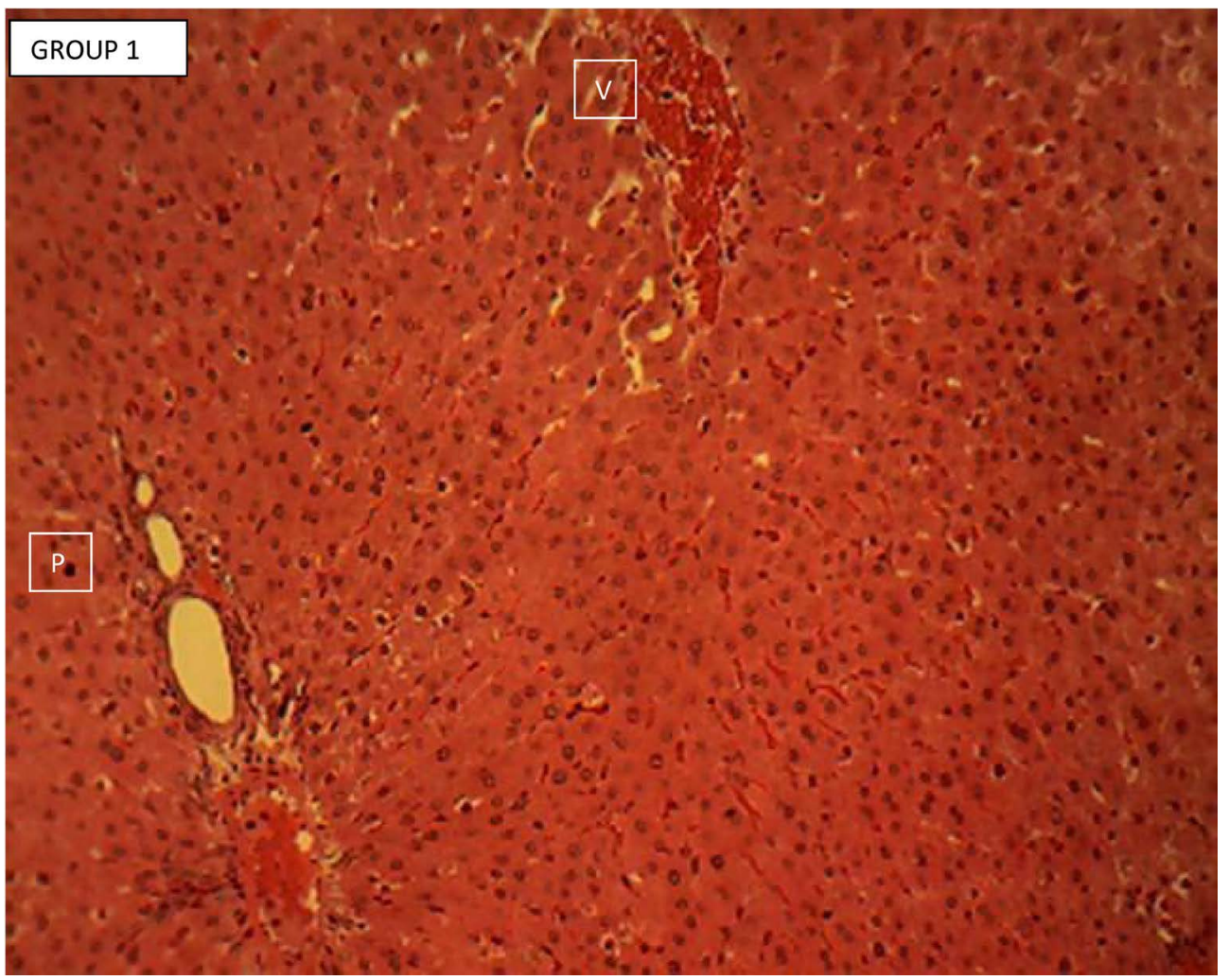

Plate 1. Liver section of normal control group 1 showing the normal histology of the rodent's liver.

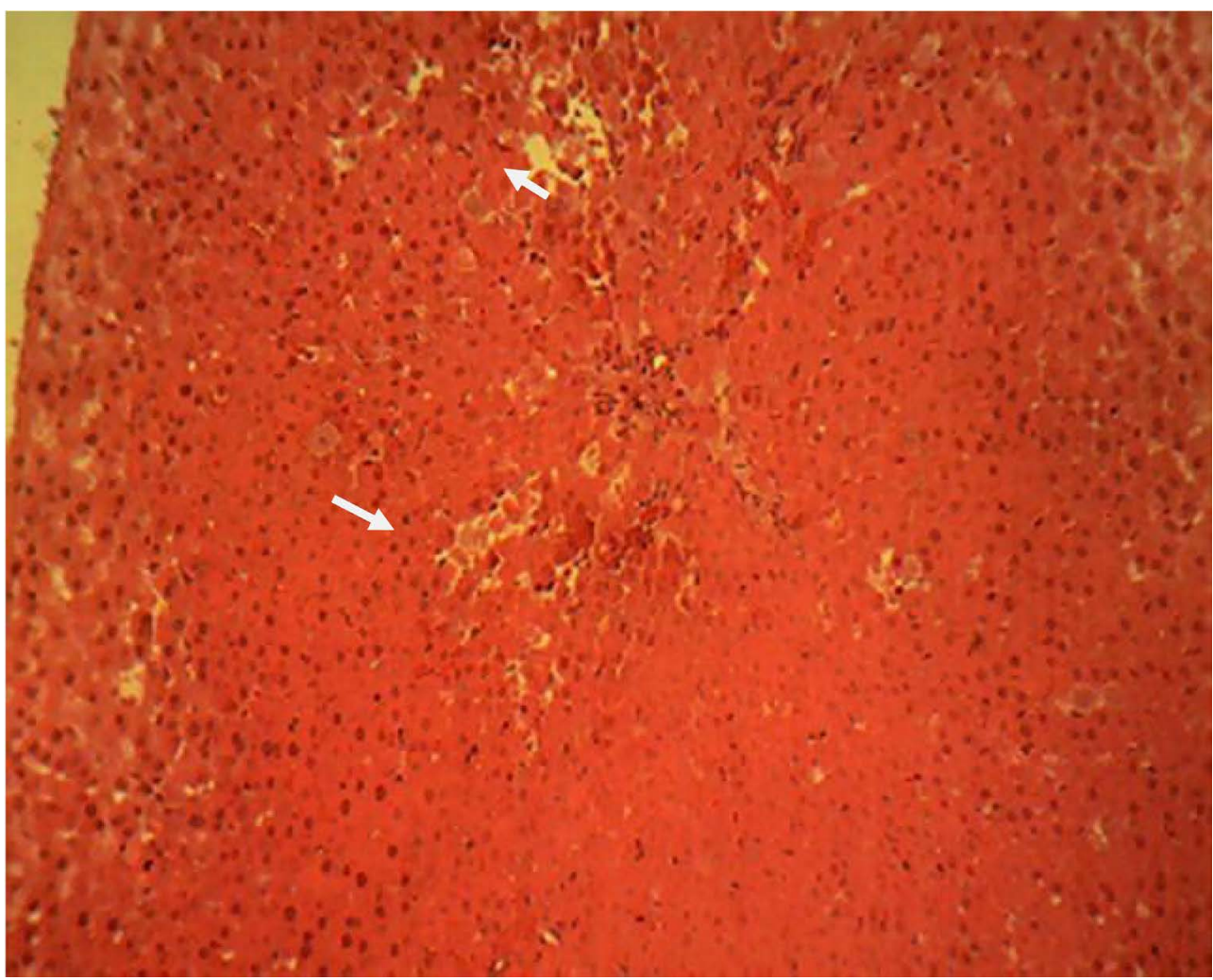

Plate 2. Liver section of acetaminophen treated group 2 showing a randomly multifocal necrosis of the hepatocytes (arrow). 


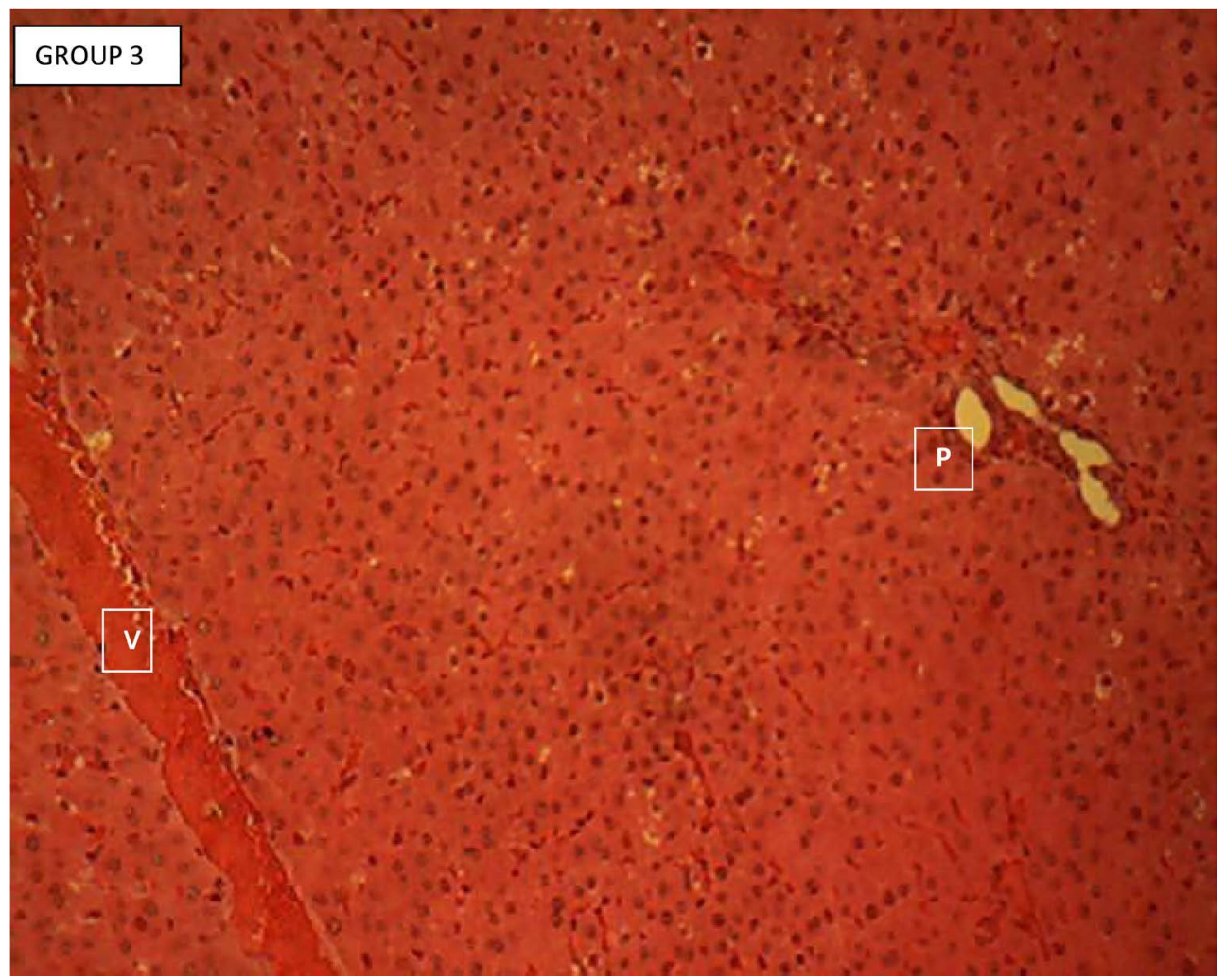

Plate 3. Liver section of standard control (group 3) showing the normal histology of the rodent liver.

Of the rodent's liver. Each section showed hepatic lobules with central veins (V) surrounded by hepatocytes arranged in radially oriented interconnecting cords, seperated by normal sized hepatic sinusoids. The hepatic cords appear to terminate at the periphery of the hepatic lobules where they meet with the components of the portal area (hepatic artery, hepatic vein and bile ductule). Portal area (P). H \& E $\times 160$.

\section{Liver section of group 4}

Liver section of group 4 (Plate 4) showed the normal histology of the rodent's liver. Each section showed hepatic lobules with central veins (V) surrounded by hepatocytes arranged in radially oriented interconnecting cords, seperated by normal sized hepatic sinusoids. The hepatic cords appear to terminate at the periphery of the hepatic lobules where they meet with the components of the portal area (hepatic artery, hepatic vein and bile ductule). Portal area (P). H \& E ×160.

\section{Liver section of group 5}

Liver section of group 5 (Plate 5) showed a moderately random macro vessicular steatosis of the hepatocytes in the periportal areas. The affected hepatocytes show a single intra-cytoplasmic clear vacuole (arrow). Central vein (V); Portal area (P). H \& E $\times 160$.

\section{Liver section of group 6}

Liver section of group 6 (Plate 6) showed a moderate to severe degeneration of the periportal and midzonal hepatocytes. The affected cells appear swollen, pale and contain numerous minute intracytoplasmic clear vacuoles. Note that the 


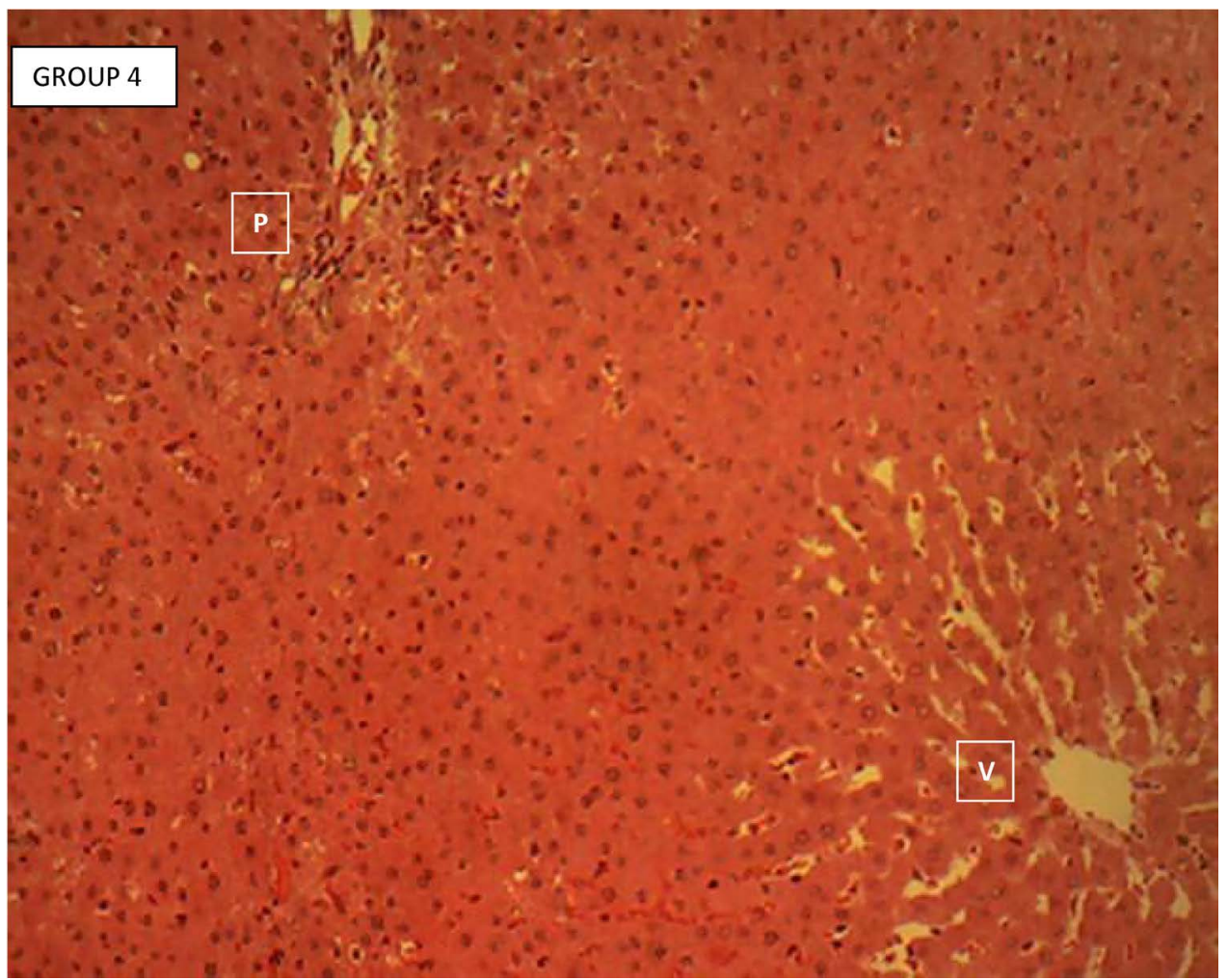

Plate 4. Liver section of mesocarp extract ( $200 \mathrm{mg} / \mathrm{kgbw})$ pre-treated and acetaminophen group 4 showing the normal histology of the rodent's liver.

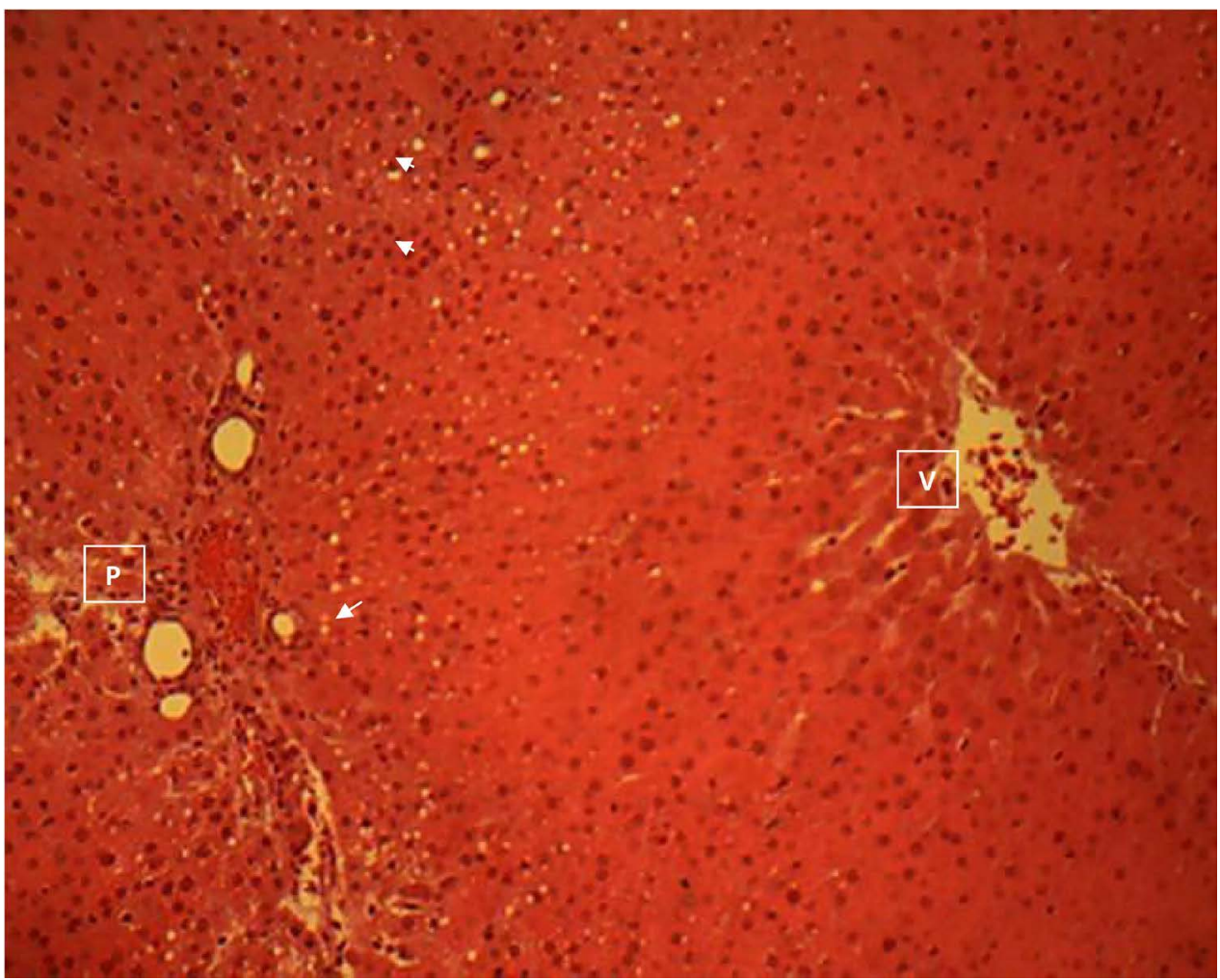

Plate 5. liver section of mesocarp extract $(400 \mathrm{mg} / \mathrm{kgbw})$ pre-treated and acetaminophen group 5 showing a moderately random macro-vessicular steatosis of the hepatocytes in the periportal areas. 


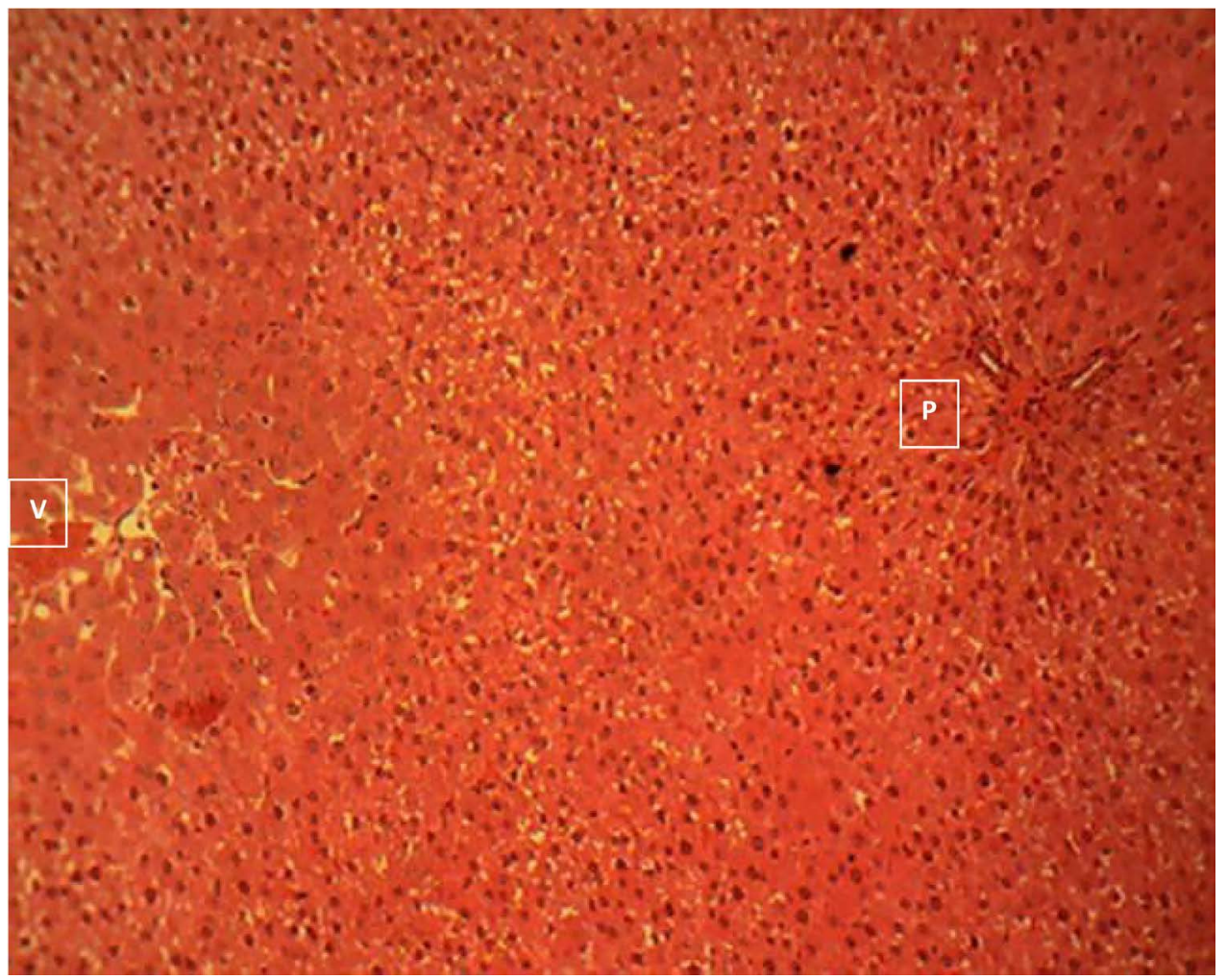

Plate 6. Liver section of endocarp/exocarp extract $(200 \mathrm{mg} / \mathrm{kgbw})$ pre-treated and acetaminophen group 6 showing a moderate to severe degeneration of the periportal and midzonal hepatocytes.

centrilobular hepatocytes (hepatocytes directly surrounding the central vein) are normal. Portal area (P); central vein (V). H \& E ×160.

\section{Liver section of group 7}

Liver section of group 7 (Plate 7) showed a marked necrosis of the hepatocytes in the periportal areas (P) of the hepatic lobules. The affected areas (arrow) are moderately infiltrated by mononuclear phagocytic cells. Central vein (V). H $\& \mathrm{E} \times 160$.

\section{Liver section of group 8}

Liver section of group 8 (Plate 8) showed a mild, random, centrilobular hepatocellular necrosis with infiltration of mononuclear phagocytes (arrow). Central vein (V); Portal area (P). H \& E $\times 160$.

\section{Liver section of group 9}

Liver section of group 9 (Plate 9) showed the normal histomorphology of the rodent's liver. Central vein (V); Portal area (P).H \& E ×160.

\subsection{Discussion}

This research comparatively evaluated the ability of the various parts of $C$. lanatus namely; the mesocarp/exocarp, endocarp aqueous etracts and the ethanol extract of the seeds to protect the liver against acetaminophen-induced liver toxicity. The qualitative and quantitative phytochemical compositions of the extracts were done followed by administration of the extracts to albino rats after 


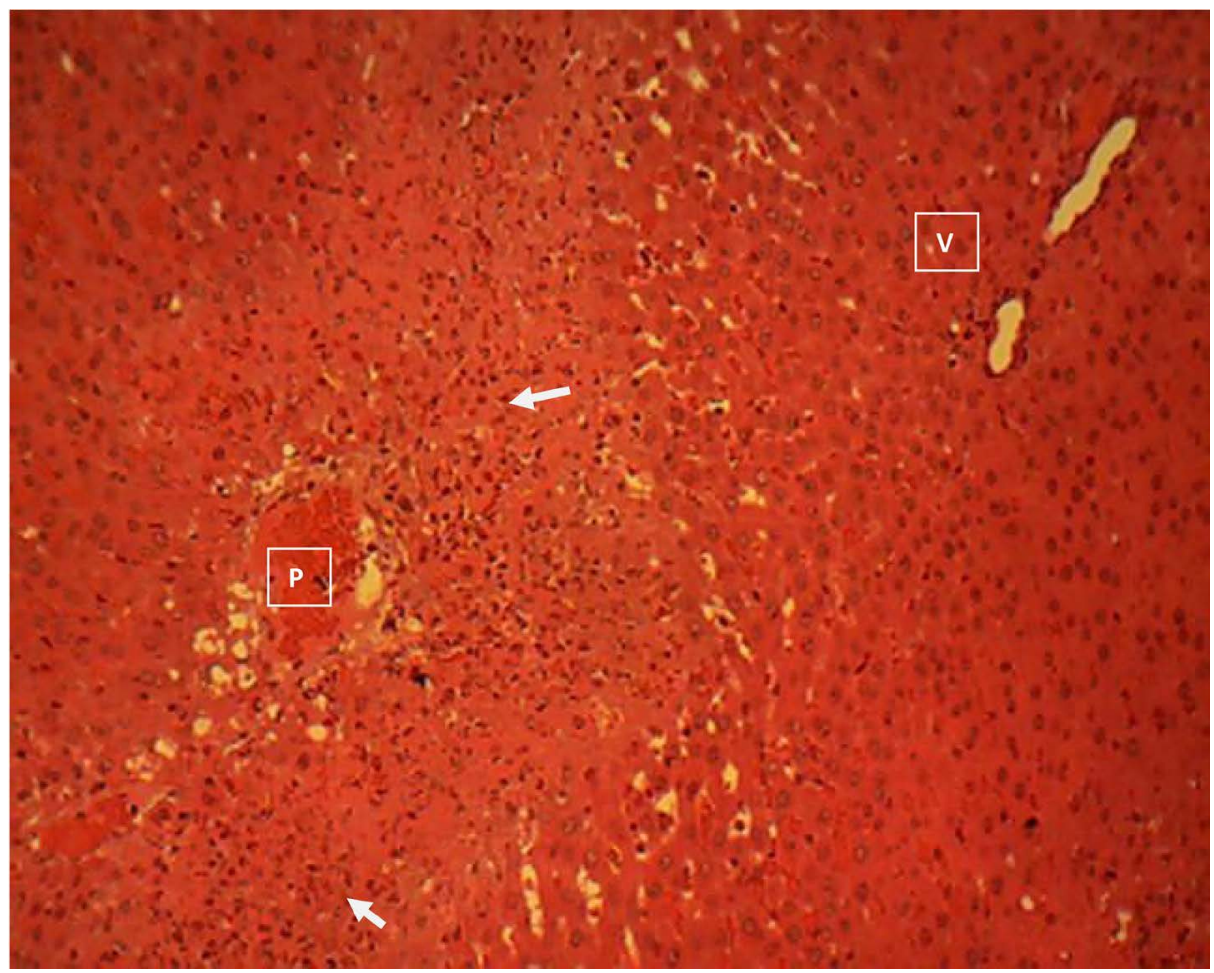

Plate 7. Liver section of endocarp/exocarp extract $(400 \mathrm{mg} / \mathrm{kgbw})$ pre-treated and acetaminophen group 7 showing a marked necrosis of the hepatocytes in the periportal areas $(\mathrm{P})$ of the hepatic lobules.

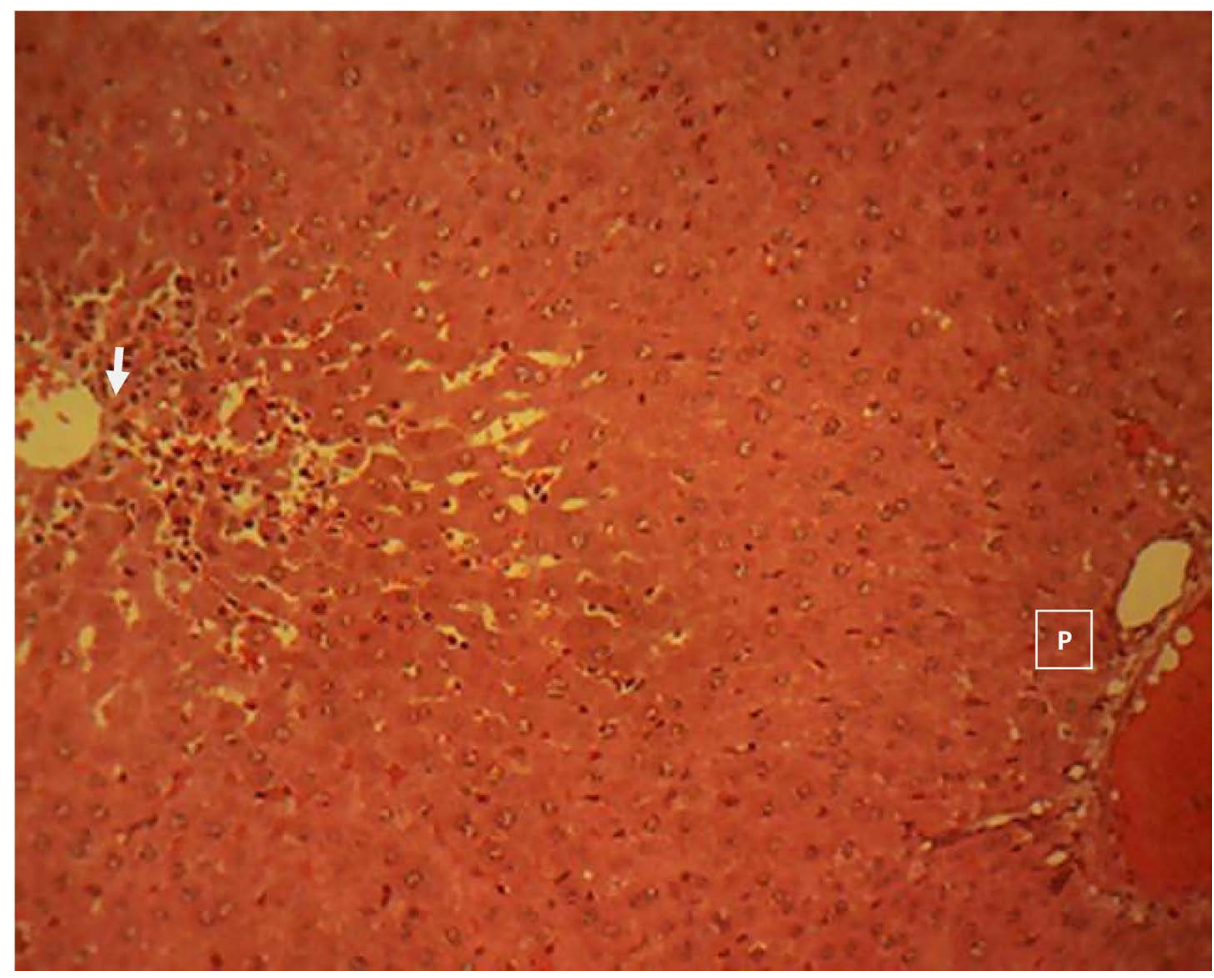

Plate 8. Liver section of seeds extract $(200 \mathrm{mg} / \mathrm{kgbw})$ pre-treated and acetaminophen group 8 showing a mild, random, centrilobular hepatocellular necrosis with infiltration of mononuclear phagocytes (arrow). 


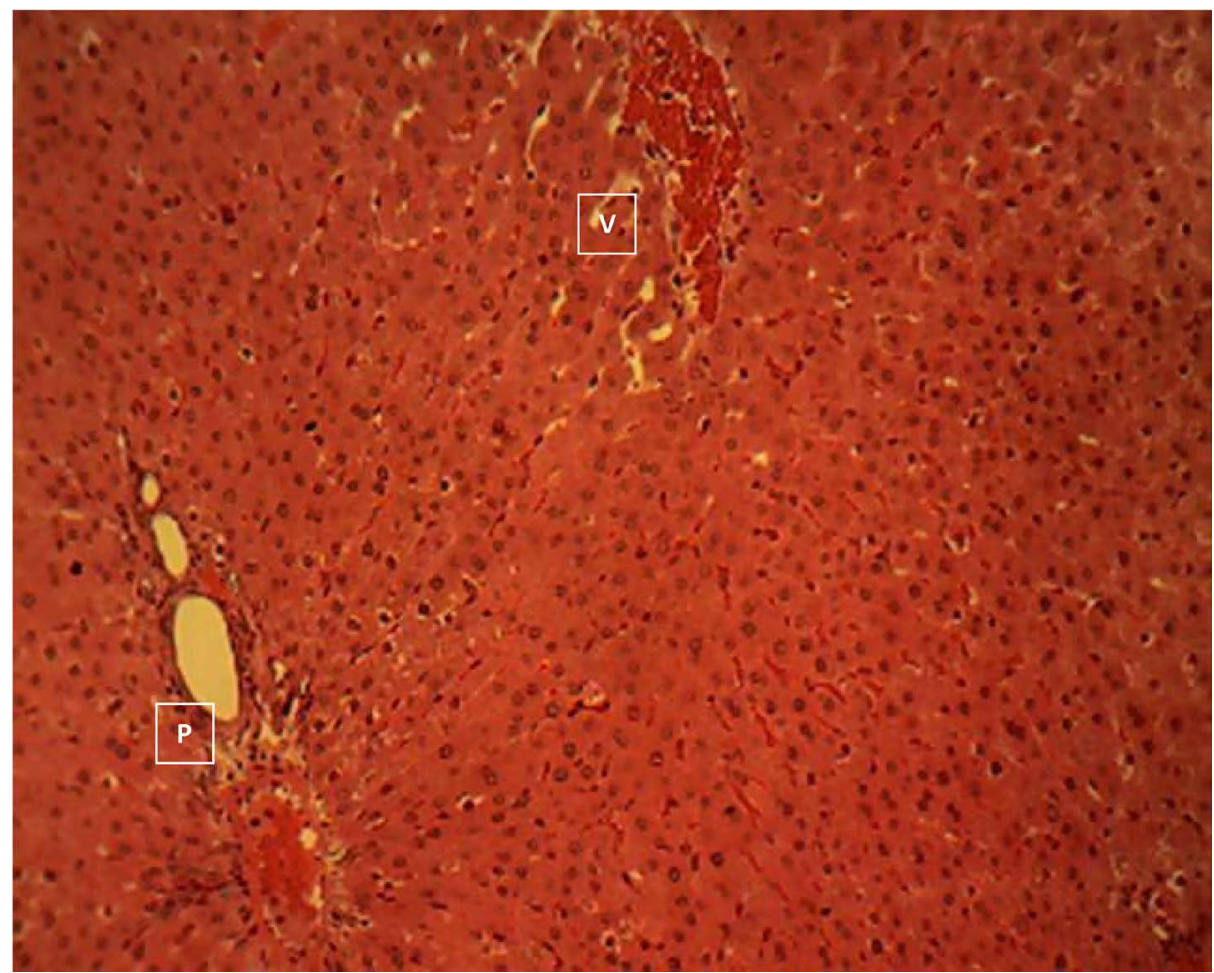

Plate 9. Liver section of seeds extract $(400 \mathrm{mg} / \mathrm{kgbw})$ pre-treated and acetaminophen group 9 showing the normal histomorphology of the rodent's liver.

which blood samples and the liver were collected for analysis. The quantitative phytochemical analysis showed that glycosides were higher in the endocarp/exocarp $(6.40 \pm 0.04 \mathrm{mg} / 100 \mathrm{~g})$ followed by the mesocarp $(6.20 \pm .24$ $\mathrm{mg} / 100 \mathrm{~g}$ ) and absent in the seeds. The concentration of total phenolics was $(7918.56 \pm 181.58 \mathrm{mg} / 100 \mathrm{~g})$ in the mesocarp, $7108.61 \pm 286.50 \mathrm{mg} / 100 \mathrm{~g}$ in the endocarp and $1073.33 \pm 29.99 \mathrm{mg} / 100 \mathrm{~g}$ in the seeds respectively with its highest concentration been in the mesocarp extract and least in the seed extract. Tannins concentrations was also highest in the mesocarp $(15.62 \pm 0.01 \mathrm{mg} / 100 \mathrm{~g})$ followed by $13.64 \pm 0.26 \mathrm{mg} / 100 \mathrm{~g}$ in the endocarp and $8.44 \pm 1.56$ in the seed extracts. Flavonoids concentration was $62.13 \pm 0.87 \mathrm{mg} / 100 \mathrm{~g}$ in the seeds and absent in the endocarp and mesocarp. Alkaloids concentration in the mesocarp was $1007.51 \pm 5.42 \mathrm{mg} / 100 \mathrm{~g}$, which was the highest, followed by $588.71 \pm 24.12$ $\mathrm{mg} / 100 \mathrm{~g}$ in the endocarp and $30.80 \pm 5.73$ in the seed extracts. For steroids, the concentrations were $4.60 \pm 0.05 \mathrm{mg} / 100 \mathrm{~g}$ in the endocarp (the highest), $2.84 \pm$ $0.12 \mathrm{mg} / 100 \mathrm{~g}$ in the mesocarp and $0.19 \pm 0.01 \mathrm{mg} / 100 \mathrm{~g}$ in the seeds. Terpenoids in the mesocarp was $145.49 \pm 10.15 \mathrm{mg} / 100 \mathrm{~g}, 59.95 \pm 4.90 \mathrm{mg} / 100 \mathrm{~g}$ in the seeds and $5.20 \pm 0.50 \mathrm{mg} / 100 \mathrm{~g}$ in the endocarp/exocarp (Table 2).

Glycosides have been reported to demonstrate good antioxidant potential by inhibiting lipid peroxidation and its presence in the mesocarp and endocarp extracts implies that the two parts of $C$. lanatus may serve as good sources of antioxidants. Tannin containing plant extracts are used as astringents, against diarrhea as diuretics, against stomach and duodenal tumors among other uses as 
reported by [16]. Tannins have been found to have active medicinal benefits as many studies have shown its antioxidant potential by interfering with free radical generation in metals ions such as Iron, Copper and Zinc. The high presence of tannins in the mesocarp as revealed in this study could therefore justify the application of the mesocarp of $C$. lanatus in the treatment of some illnesses such as diarrhea, stomach and deudonal disorder among others. Alkaloids have also been reported to possess antioxidant potential by cushioning the effect of free radicals. The presence of phenolic acids in the fruit-parts extracts, especially in the mesocarp is also an advantage because phenolic acids are known to act as potent antioxidants by transferring hydrogen atom from their $\mathrm{OH}$ groups to the chain - carrying ROO' radicals thereby neutralizing its oxidative effect hence the mesocarp may be harnessed for antioxidant use. Many saponins are known to have antimicrobial properties and this research has shown its high concentration especially in the mesocarp extract, so it could also justify its use as a potential natural antibiotics agent. Terpenoids have been reported by [23], to play a role in traditional herbal remedies and under investigation for antibacterial, antineoplastics and other pharmaceutical functions. This study has also proven that the $C$. lanatus fruit parts, especially the mesocarp could effectively be used as a natural antibiotic agent to cure bacteria-related infections.

The activities of AST, ALT and ALP were significantly $(\mathrm{p}<0.05)$ increased in the negative control groups (group 2) when compared to the normal control (group 1). This observation proved that the administered dose of acetaminophen to this group without any ameliorating agent actually caused the expected inflammation of the hepatocytes and so corroborates the hypothesis that high dose of acetaminophen could be toxic to the liver. One of the possible mechanisms of acetaminophen-induced liver inflammation may be due to the generation of free radicals and or other reactive oxygen species which mount some level of overwhelming oxidative stress on the liver cells and possibly resulting to wearing out or degeneration of the liver cells. This could manifest by elevated liver enzymes in the serum as observed in this study. However, the administration of the extracts (group 4, 5, 6, 7, 8 and 9) led to a significant $(\mathrm{p}<0.05)$ decrease in the serum activities of AST and ALT when compared with the negative control group (group 2). This was a justification to the assertion that the $C$. lanatus's mesocarp, endocarp and seed extracts have the ability to reverse or protect the liver from inflammation induced by acetaminophen ingestion, this ability could be traced to its potent phytochemical constituents which have be shown to possess antioxidant properties. The administration of the extracts in group 5, 7, 8 and 9 still showed elevated activities of ALP but the increase was not significant ( $p>0.05)$ when compared to the negative control group (group 2). The non-significant $(p>0.05)$ increase in the liver enzymes in these groups could also be attributed to the antioxidant ability of the extracts which prevented further damage due to acetaminophen ingestion while the administration of the extracts in group 4 and 6 decreased ALP when compared to the negative control group (group 2). Although plasma membrane damage and protein leakage is probably the most 
common reason for elevated serum ALT, there is evidence that other mechanisms can be involved, Oncotic necrosis: [24] [25] [26] Membrane blebbing: [26] [27] [28], increased expression: [29] [30] [31] [32], macroenzymes [33] [34] [35] [36]. It has been suggested that membrane blebs containing cytosolic components form during ischemia-reperfusion injury (IRI) of the liver and that these protrusions can rupture to release aminotransferases without cell death [29] [30] [31]. This was based in part on evidence from microscopy [29] and on the finding that the cytosolic isoform of AST is released early in IRI, while the mitochondrial isoform does not increase in serum until later and correlates better with the extent of liver necrosis [30] Experimental work has also revealed that ALT and AST activity are increased in livers of mice treated with carbon tetrachloride $\left(\mathrm{CCl}_{4}\right)$, suggesting an increase in expression [32] [33].

Results of histological examination revealed that groups 1, 3 and 4 showed the normal histology of the rats liver, with each section showing hepatic lobules with central veins $(\mathrm{V})$ surrounded by hepatocytes arranged in radially oriented interconnecting cords, seperated by normal sized hepatic sinusoids. This as expected, could be due to the fact that the normal control (group 1) was devoid of the inflammatory agent (acetaminophen) while in group 3, the standard drug (silymarin) could have been able to cushion any threat posed by acetaminophen and helped the liver recorvered from its effect. And in group 4, the potency of the mesocarp which sterned from its high antioxidant effect could have ameliorated the inflammatory effect of the acetaminophen. The hepatic cords appear to terminate at the periphery of the hepatic lobules where they meet with the components of the portal area (hepatic artery, hepatic vein and bile ductule). On the other hand, sections of the liver of rats in group 2 showed a randomly multifocal necrosis of the hepatocytes, an indication of a possible inflammatory effect caused by acetaminophen as expected for the group. The liver architecture in group 5 was characterized by moderately random macro-vessicular steatosis of the hepatocytes in the periportal areas. Liver of rats in group 6 group showed a moderate to severe degeneration of the periportal and mid-zonal hepatocytes, characterized by swollen, pale and contain numerous minute intracytoplasmic clear vacuoles, also an indication of inflammatory effect. Sections of the liver presented in group 7 showed a marked necrosis of the hepatocytes in the periportal areas $(\mathrm{P})$ of the hepatic lobules, a pointer to the possibility that the liver of rats in this group could have been challenged. Group 8 liver showed a mild, random, centrilobular hepatocellular necrosis with infiltration of mononuclear phagocytes. Sections of the liver of rats in group 9 showed normal histomorphology, indicating that there was no negative effect on the liver of rats in this group. This implied that $400 \mathrm{mg} / \mathrm{kg}$ of the seed extract pre-treatment for two (2) weeks protected the liver from inflammation by acetaminophen.

\section{Conclusion}

In this study, the phytochemical compositions of aqueous extracts of the meso- 
carp, endocarp/exocarp, and ethanol seed extract of $C$. lanatus as well as the analysis of serum liver enzymes activities and photomicrograph images of liver sections of acetaminophen intoxicated rats pre-treated with the extracts were performed. The results obtained from the study indicated that the aqueous extracts of the mesocarp and endocarp/exocarp as well as the ethanol seed extract of $C$. lanatus were rich in phytochemical compounds which possibly accounted for their ability to reduce elevated liver function biomarker enzymes intoxicated by acetaminophen, but only the $200 \mathrm{mg} / \mathrm{kg}$ of mesocarp and $200 \mathrm{mg} / \mathrm{kg}$ of the seed extracts clearly protected the liver from inflammation as shown in the photomicrograph images.

\section{Acknowledgements}

The authors are grateful to Emzor Pharmaceuticals Ltd. Lagos, Nigeria which through the instrumentality of Mr. Bonaventure Enemali, provided the acetaminophen used for the research. We also appreciate the professional advice by Prof. T.O. Bamidele and the Laboratory Technologists in the Department of Biochemistry and Molecular Biology, Nasarawa State University, Keffi for helping out with the sample extraction and analysis protocols.

\section{Conflicts of Interest}

The authors declare no conflicts of interest regarding the publication of this paper.

\section{References}

[1] Bailey, L.H. (1930) Three Discussions in Cucurbitaceae. Gentes Herbarum, 2, 175-186.

[2] Chomicki, G. and Renner, S.S. (2014) Watermelon Origin Solved with Molecular Phylogenetics Including Linnaean Material: Another Example of Museomics. New Phytologist, 205, 526-532. https://doi.org/10.1111/nph.13163

[3] Maynard, D. and Donald, N. (2012) 6: Cucumbers, Melons and Watermelons. In: Kiple, K.F. and Ornelas, K.C., Eds., The Cambridge World History of Food, Part 2, Medical History, 46, Cambridge University Press, Cambridge, 267-270.

[4] Erhirhie, E.O. and Ekene, N.E. (2013) Medicinal Values on Citrullus lanatus (Watermelon): Pharmacological Review. International Journal of Research in Pharmaceutical and Biomedical Sciences, 4, 1305-1312.

[5] Charoensiri, R., Kongkachuichai, R., Suknicom, S. and Sungpuag, P. (2009) Beta-Carotene, Lycopene, and Alpha-Tocopherol Contents of Selected Thai Fruits. Food Chemistry, 113, 202-207. https://doi.org/10.1016/j.foodchem.2008.07.074

[6] Altaş, S., Kızıl, G., Kızıl, M., Ketani, A. and Haris, P.I. (2011) Protective Effect of Diyarbakır Watermelon Juice on Carbon Tetrachloride-Induced Toxicity in Rats. Food and Chemical Toxicology, 49, 2433-2438.

https://doi.org/10.1016/j.fct.2011.06.064

[7] Collins, J.K., Wu, G., Perkins-Veazie, P., Spears, K., Claypool, P.L., Baker, R.A. and Clevidence, B.A. (2007) Watermelon Consumption Increases Plasma Arginine Concentrations in Adults. Nutrition, 23, 261-266.

https://doi.org/10.1016/j.nut.2007.01.005 
[8] Perkins-Veazie, P., Collins, J.K., Pair, S.D. and Roberts, W.(2001) Lycopene Content Differs Among Red-Fleshed Watermelon Cultivars. Journal of the Science of Food and Agriculture, 81, 983-987. https://doi.org/10.1002/jsfa.880

[9] Akashi, K., Nishimura, N., Ishida, Y. and Yokota, A. (2004) Potent Hydroxyl Radical-Scavenging Activity of Drought-Induced Type-2 Metallothionein in Wild Watermelon. Biochemical and Biophysical Research Communications, 323, 72-78. https://doi.org/10.1016/j.bbrc.2004.08.056

[10] Chaturvedi, P., Pipedi-Tshekiso, M. and Tumedi, A. (2014) Supplementation with Watermelon Renders Protection Against Toxicity Induced by Paracetamol in Albino Rats: The Mutual and Fine Interaction of Antioxidants Prevented the Cellular Damage. International Journal of Food, Agriculture \& Veterinary Sciences, 4, 102-111.

[11] Alok, B.R.K., Vivek, D. and Niyaz, A. (2012) Evaluation of Anti-Ulcer Activity of Citrallus lanatus Seed Extract in Wistar Rats. Journal of Pharmaceutical Sciences, 4 , 135-139.

[12] National Plant Data Center, NRCS, USDA (2000) Baton Rouge, LA 70874-4490 USA. Citrullus lanatus var. lanatus, the Plants Database, Database (Version 5.1.1). http://plants.usda.gov

[13] Van Gulik, T.M., De Graaf, W, Dinant, S., Busch, O.R.C. and Gouma, D.J. (2007) Vascular Occlusion Techniques during Liver Resection. Digestive Surgery, 24, 274-281. https://doi.org/10.1159/000103658

[14] Tortora, G., Derrickson, J. and Bryan, H. (2008) Principles of Anatomy and Physiology. 12th Edition, John Wiley \& Sons, Hoboken, 945.

[15] Maton, A., Jean, H., Charles, W., Mclaughlin, S. Johnson, M., Quon, W., David, L. and Jill, D.W. (1993) Human Biology and Health. Prentice Hall, Englewood Cliffs.

[16] Mamta S., Jyoti, S., Rajeev, N., Dhatmendra, S. and Abhishek, G. (2013) Phytochemistry of Medicinal Plants. Journal of Pharmacognosy and Phytochemistry, 1, 168-182.

[17] Narasinga, R. (2003) Bioactive Phytochemicals in Indian Foods and Their Potential in Health Promotion and Disease Prevention. Asia Pacific Journal of Clinical Nutrition, 12, 9-22.

[18] Harborne, J.B. (1973) Phytochemical Methods: A Guide to Modern Technique of Plant Analysis. Chapman and Hall, London, 107-150.

[19] Trease, G.E. and Evans, W.C. (1989) Pharmacognosy. 13th Edition, Bailliere Tindall Books Publishers, London, 1-105.

[20] Sofowora, A. (1993) Screening Plants for Bioactive Agents. In: Medicinal Plants and Traditional Medical in Africa. 2nd Edition, Spectrum Books Ltd., Sunshine House, 134-156.

[21] Reitman, S. and Frankel, S. (1957) A Colorimetric Determination of Oxaloacetic and Glutamic Pyruvic Transaminases. American Journal of Clinical Pathology, 28, 56-63. https://doi.org/10.1093/ajcp/28.1.56

[22] Bancroft, J.D. and Stevens, M. (2002) Theory and Practice of Histological Techniques. Churchill Livingstone, Edinburgh, 16-64.

[23] Nita, Y., Rajesh, Y. and Anju, G. (2014) Chemistry of Terpenoids. International Journal of Pharmaceutical Sciences Review and Research, 27, 272-278.

[24] Leist, M., Gantner, F., Bohlinger, I., Tiegs, G., Germann, P.G. and Wendel, A. (1995) Tumor Necrosis Factor-Induced Hepatocyte Apoptosis Precedes Liver Failure in Experiment Murine Shock Models. The American Journal of Pathology, 146, $1220-1234$. 
[25] Lawson, J.A., Fisher, M.A., Simmons, C.A., Farhood, A. and Jaeschke, H. (1998) Parenchymal Cell Apoptosis as a Signal for Sinusoidal Sequestration and Transendothelial Migration of Neutrophils in Murine Models of Endotoxin and Fas-Antibody-Induced Liver Injury. Hepatology, 28, 761-767. https://doi.org/10.1002/hep.510280324

[26] Lemasters, J.J., Ji, S. and Thurman, R.G. (1981) Centrilobular Injury Following Hypoxia in Isolated, Perfused Rat Liver. Science, 213, 661-663. https://doi.org/10.1126/science.7256265

[27] Kamiike, W., Fujikawa, M., Koseki, M., Sumimura, J., Miyata, M., Kawashima, Y., et al. (1989) Different Patterns of Leakage of Cytosolic and Mitochondrial Enzymes. Clinica Chimica Acta, 185, 265-270. https://doi.org/10.1016/0009-8981(89)90216-7

[28] Gores, G.J., Herman, B. and Lemasters, J.J. (1990) Plasma Membrane Bleb Formation and Rupture: A Common Feature of Hepatocellular Injury. Hepatology, 11, 690-698. https://doi.org/10.1002/hep.1840110425

[29] Pappas, N.J. (1980) Increased Rat Liver Homogenate, Mitochondrial, and Cytosolic Aspartate Aminotransferase Activity in Acute Carbon Tetrachloride Poisoning. Clinica Chimica Acta, 106, 223-229. https://doi.org/10.1016/0009-8981(80)90175-8

[30] Pappas, N.J. (1986) Source of Increased Serum Aspartate and Alanine Aminotransferase: Cycloheximide Effect on Carbon Tetrachloride Hepatotoxicity. Clinica Chimica Acta, 154, 181-189. https://doi.org/10.1016/0009-8981(86)90029-X

[31] Pappas, N.J. (1989) Theoretical Aspects of Enzymes in Diagnosis. Why Do Serum Enzymes Change in Hepatic, Mitochondrial, and Other Diseases? Clinics in Laboratory Medicine, 9, 595-626. https://doi.org/10.1016/S0272-2712(18)30594-8

[32] Aubert, J., Begriche, K., Delannoy, M., Morel, I., Pajaud, J., Ribault, C., et al. (2012) Differences in Early Acetaminophen Hepatotoxicity between Obese $o b / o b$ and $d b / d b$ Mice. Journal of Pharmacology and Experimental Therapeutics, 342, 676-687. https://doi.org/10.1124/jpet.112.193813

[33] Konttinen, A., Murros, J., Ojala, K., Salaspuro, M., Somer, H. and Räsänen, J. (1978) A New Cause of Increased Serum Aspartate Aminotransferase Activity. Clinica Chimica Acta, 84, 145-147. https://doi.org/10.1016/0009-8981(78)90487-4

[34] Kajita, Y., Majima, T., Yoshimura, M., Hachiya, T., Miyazaki, T., Ijichi, H., et al. (1978) Demonstration of Antibody for Glutamic Pyruvic Transaminase (GPT) in Chronic Hepatic Disorders. Clinica Chimica Acta, 89, 485-492. https://doi.org/10.1016/0009-8981(78)90414-X

[35] Moriyama, T., Nobuoka, M. and Makino, M. (1990) Incidence and Properties of Aspartate Aminotransferase-Immunoglobulin Complexes in Patients with a High Serum Aspartate to Alanine Aminotransferase Ratio. Clinica Chimica Acta, 190, 47-56. https://doi.org/10.1016/0009-8981(90)90279-2

[36] Briani, C., Zaninotto, M., Forni, M. and Burra, P. (2003) Macroenzymes: Too Often Overlooked. Journal of Hepatology, 38, 119. https://doi.org/10.1016/S0168-8278(02)00333-1 